\title{
Assessment Model Measuring Key Success Factors in Co-operative Financial Institutions to Improve Penetration Rate
}

\author{
Bouba Ismaila \\ https://orcid.org/0000-0002-6753-5873 \\ University of KwaZulu-Natal \\ 217076451@stu.ukzn.ac.za
}

\author{
Vangeli Gamede \\ https://orcid.org/0000-0003-1531-0725 \\ University of KwaZulu-Natal \\ gamede@ukzn.ac.za
}

\section{Abstract}

Research purpose: This study aims to determine the reasons for the low penetration rate of the South African co-operative financial institution (CFI) sector; and to recommend a valid and reliable tool for assessing key success factors of CFIs. Little research has previously been undertaken on why the South African CFI sector remains small, with a penetration rate of just $0.1 \%$.

Research design, approach and method: This study used a quantitative design to evaluate objective data. A structured questionnaire was used to collect data from 303 consumers around Tshwane, and from 20 registered CFI representatives around the country. The SPSS software was used to analyse the data.

Main findings: The study revealed that the low penetration rate of the CFI sector is due to consumers' lack of knowledge about them, their products and activities. An assessment model has been proposed to help address the issue.

Practical implication: The assessment model could be a useful tool for CFIs and other micro-credit lenders, as it aims to assist in measuring the effectiveness of their innovation and entrepreneurial strategies and then to initiate the necessary steps and training programmes to address the problem.

Original value: The study findings provide empirical evidence on possible reasons for the low penetration rate of South African CFIs; and the proposed assessment model may help to improve membership growth and performance in the sector; particularly as no prior study has been conducted to determine the possible reasons for such a low penetration rate of SA co-operative financial institutions.

Keywords: co-operative financial institutions; penetration rate; entrepreneurial innovativeness; offensive strategies; corporate social responsibility; marketing, education, partnership, differentiation strategies

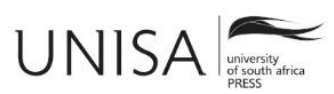




\section{Introduction}

It is important to explain and define the concepts "co-operatives" and "co-operative financial institutions." The Companies and Intellectual Property Commission (CIPC) defines a co-operative as a distinct form of company that provides services and/or products to its members; and profits or surpluses are shared among members in relation to the amount of the business each of them did with the co-operative (CIPC 2017). The goal is for the members to achieve individual and collective financial emancipation. Types of co-operatives include savings and credit co-operatives; agricultural, marketing, housing, financial services and consumer service co-operatives; and crafts and burial societies. To make the co-operative effective, members meet regularly to share detailed reports and elect directors from among themselves (Entrepreneur 2009). The directors are responsible for employing managers to carry out the day-to-day tasks to serve the members' interests.

Financial co-operatives offer opportunities for financial inclusion, improving a society's socioeconomic profile, and that of the participating individuals. Sauli (n.d., 5) states that co-operative financial institutions (CFIs) provide many of the same products and services as commercial banks, but they differ in several ways since they do not seek to maximise profit, but rather serve their adherents, by whom they are owned. They generally have lower service and interest charges compared to commercial banks; and the excess returns to the adherents as profit or investment shares (Sauli n.d., 5). To emphasise the importance of financial co-operatives, Birchall $(2013,11)$ argues that financial co-operatives are a much better alternative to commercial banks, especially at a time of financial crisis. This underlines the importance of a study on CFIs.

It is fair to say that South Africa has one of the most sophisticated financial sectors in the world, using the latest information and communication technologies. However, the Bank Association South Africa (2017) states that financial inclusion remains a huge challenge facing South Africa. A substantial portion of the population does not benefit from the sector and "many communities in rural areas are living in poor conditions" (Van der Walt 2008, 1).

\section{Problem Statement and Objectives}

The problem this article aims to address is that of the many challenges that are faced by financial co-operatives in South Africa, and which have not been investigated before: the reasons for the low penetration of the sector. The World Council of Credit Union's (WOCCU) report $(2018,2)$ revealed that the co-operative financial institution sector in South Africa is very small compared to other African countries, with a penetration rate of just $0.1 \%$. Mushonga, Arun, and Marwa $(2018,69)$ argue that, in spite of the overall resilience of the CFI movement coming out of the recent global financial crisis, with remarkable growth in numbers and participation, South Africa is going backwards. The study seeks to discover the reasons for this, from the consumer and supplier points of view, and to propose how to fix the problem. Thus, the objective of the study is to 
determine the reasons for the low penetration rate of South African CFIs by investigating consumer awareness of CFIs; the key success factors or strategies of CFIs may also indicate their entrepreneurial innovativeness, and the adoption of these strategies by CFIs; and then to propose an assessment tool to help improve the sector penetration rate and performance.

\section{Literature Review}

The literature review consists of the studies that were the lens through which this study approached its theoretical inquiry into the reasons for the low penetration rate of the South African CFI sector; and developed a possible assessment model.

\section{Theoretical Framework}

Studies on co-operatives and CFIs and their contribution to financial inclusion across the world, such as those of the South African Department of Trade and Industry (DTI) (2012); Peels (2013); Philip (2003); Finmark Trust (2014); Birchall (2013); and the World Bank (2014), report that the South African CFI sector remains small, with a low penetration rate compared to that of other countries. Other studies have looked at the importance of entrepreneurship and innovation for CFIs (Christensen 2004; Hill 2003; Holtzman 2014; Molokwu, Barreria, and Urban 2013; Ireland, Kuratko, and Morris 2006; Oluwatayo 2012; Van Vuuren, Groenewald, and Gantsho 2009).

\section{Co-operatives and Co-operative Financial Institutions}

According to the International Co-operative Alliance (ICA), whether the participants of co-operatives are the clients, workers, or members, they possess the same decisionmaking power on anything the co-operative organises, and all share in a portion of the returns (ICA 2015). The Alliance goes on to say that "as businesses driven by values, not just profit, co-operatives share internationally agreed principles and act together to build a better world through co-operation" (ICA 2015).

Peels $(2013,2)$ summarises the characteristics of financial co-operatives, highlighting the difference between investor-owned banks and CFIs. Clients own the co-operative, everyone with one member-share; and the financial co-operative is not just the property of the present group of participants, it also belongs to future associates (Peels 2013, 2). Association is not transferrable; participants manage the financial co-operative; and they are a full party in the administration of the institution (Peels 2013,2). Members are the core recipients of the benefits, since the co-operative's aim is not to capitalise on profit. Given these characteristics and operating principles, the aim of financial cooperatives should be the growth and development of their member-owners instead of profit maximisation for shareholders, as in the case of investor-owned banks. It is, therefore, important to address the elusive financial inclusion issue for financial cooperatives' members, and society at large. The following section looks at how other countries have managed to make their CFI sector more successful. 


\section{International Best Practices}

Co-operative financial institutions have had many successes internationally over the years. A study by the DTI of the successful models adopted by Italy, Canada, Spain, India, Kenya and Bangladesh, shows that, in each case, the state has taken a leading role in the development of the co-operative sector (DTI 2012, 20-27). However, the main responsibility to make the sector a success remains that of the co-operatives themselves. In Lithuania, Jaseviciene, Kèdaitis, and Vidzbelyte $(2014,127)$ found that effective advertising can help credit unions to attract new members and to choose certain strategies in order to create a credit union's public image. In North America, one of the key success factors of a Canadian credit union is diversification of "delivery channels," which focuses on enhancing the existing channels and developing new channels, such as wireless access and locating branches in grocery stores so that consumers can transact easily in any way they wish to (Schoemaker et al. 2002, 24). Odhiambo $(2019,49)$ found that Kenyan SACCOS's revenue rises with membership.

In today's business world, many organisations have adopted corporate social responsibility strategies to gain a better share of the market. In this regard, McWilliams, Siegel, and Wright $(2006,1)$ argue that corporate social responsibility (CSR) activities have been conceived to infuse social qualities or characteristics into goods and manufacturing methods, adopting changing human resource management practices, and pushing for the goals of community organisations. Differentiation is another strategy companies use to attract customers in this ever-changing market environment. For instance, Australia's first customer-owned bank, Bankmecu, appeals to young people through its e-statements; interactive mobile app; conversations on social media; and its visual-centred, user-friendly branding (WOCCU 2015, 10). On the other hand, Mushonga et al. $(2018,263)$ found that a CFI performance inhibitor is the inability to retain talent through competitive market salaries, leading to poor performance and a lack of interest from the public.

The case of Kenya is more relevant to South Africa. The Kenyan co-operative and CFI sector appears to be the best example of African success. The World Council of Credit Unions' (WOCCU) statistical report for 2018 placed the Kenyan CFI sector as number one in Africa, with close to 8 million members and a $28.4 \%$ penetration rate. The country has a well-developed co-operative financial sector with many successes. With more than $\$ 2.133$ billion US in assets and a savings collection of approximately $\$ 1.76$ billion US, the savings and credit co-operative (SACCO) sector in Kenya has garnered a considerable share (about 20\%) of the nation's savings (Gogo and Oluoch 2017, 2410).

Key Kenyan co-operative success factors include an enabling legislative environment. Supporting this, Mathuva $(2016,6)$ asserts that the "growth in membership is partly attributed to the regulatory reforms between 2008 and 2010, which allowed SACCOs in Kenya to expand operations and target members who are not necessarily from the 
field of membership defined by the common bond." This author's study revealed that SACCOs with greater growth in members enjoy higher returns (Mathuva 2016, 7).

Kinyua, Amuhaya, and Namusonge $(2015,142)$ identify specific strategies that are applied to manage stakeholders' interests in Kenyan SACCOs, and which have greatly contributed to their overall success. Some of them were used as main variables in the conceptual model in this study. These strategies are briefly discussed below:

\section{Defensive Strategies}

Defensive strategies are management tools that can be used to counter an attack from a potential competitor (Kinyua et al. 2015, 142).

\section{Offensive Strategies}

According to Karakaya and Yannopoulos (2011, 5), firms engage in offensive marketing strategies to improve their own competitive positions by taking market share away from rivals. Offensive strategies may consist of direct and indirect attacks, or moving into new markets to avoid current competitors.

\section{Hold Strategies}

Hold strategies involve maintaining the current position, such as in the market-place and shares (Kinyua et al. 2015, 143).

\section{Swing Strategies}

Swing strategies refer to any group of stakeholders with highly co-operative and highly threatening abilities, with whom firms should collaborate to maximise their positive influencing abilities and minimise their threatening abilities (Freeman and McVea 2001, in Kinyua et al. 2015, 22).

\section{Corporate Social Responsibility Strategies (CSR)}

McWilliams et al. $(2006,1)$ define corporate social responsibility as the firm going beyond "compliance and engages in actions that appear to further some social good beyond the interests of the firm and that which is required by law."

\section{Use of Technology and Partnership}

In Kenya, based on a World Council Developed Network that connects credit unions to the Safaricom's M-PESA (mobile money services) platform, members are not only able to use M-PESA's standard payment services, but can also integrate their regular credit union accounts with the mobile interface (WOCCU 2015).

Some of the above strategies were used as variables to design a conceptual model that was tested in this empirical study to measure general consumer awareness of the key success factors of South African CFIs, while also showing how entrepreneurial and 
innovative South African CFIs are in their endeavours to grow their membership base and the sector. According to Hill (2003, 32), entrepreneurship is a measure of a business's risk-taking ability-meaning what level of risk a business is willing to take to be successful. Innovation is the ability to introduce "a new product or a new product quality; the introduction of a new production process; the opening-up of a new market; the use of new raw materials or sources of semi-manufactured materials; and the creation of a new industry business, such as the establishment of a monopoly situation to breakdown a monopoly" (Kassa and Raju 2014, 53). This suggests that organisations like CFIs need to review their practices to become innovative to exercise agility; grow their revolutionary dimension; and become attractive (Van Vuuren et al. 2009, 325).

The question is whether some of these successful models and strategies can be adopted by the CFI sector in South Africa, resulting in a successful financial co-operative sector aimed at achieving decent living conditions, financial independence and, indeed, economic development for its communities? The answer may be "yes." However, this article argues that the process should start with consumer education and proper marketing, and CFI engagement with communities, so that they can become aware of CFIs and the products or services and benefits they offer.

\section{Research Method and Design}

The study design and data collection method were determined by the need to gather enough data to investigate consumer awareness (or lack thereof) of CFIs, and their entrepreneurial and innovative actions or strategies such as marketing; education; partnerships; corporate social responsibilities; offensive strategies; and differentiation, from both the supplier and consumer perspectives. A quantitative research design was deemed appropriate to investigate these activities. This required an empirical study with data collection from participants, which was achieved using questionnaires. A conceptual framework, based on the Kenyan SACCO strategies mentioned earlier, and other studies from different authors around the world (Boysen and Sahlberg 2008; Corcoran and Wilson 2010; Paredes 2008; Strandberg 2010; Smakalova 2012; WOCCU 2015), was used as a guide for the study and is presented in figure 1. It shows the various independent variables and the dependent variable, which is effective entrepreneurial innovativeness. 
Ismaila, Gamede

\begin{tabular}{|c|c|c|c|c|c|}
\hline \multicolumn{6}{|c|}{ ORGANISATIONAL ACTIONS THAT INFLUENCE ENTREPRENEURIAL INNOVATIVENESS } \\
\hline Marketing & \begin{tabular}{|l|} 
Educating \\
consumers
\end{tabular} & Partnerships & Differentiation & $\begin{array}{l}\text { Corporate social } \\
\text { responsibility }\end{array}$ & $\begin{array}{l}\text { Offensive } \\
\text { strategies }\end{array}$ \\
\hline $\begin{array}{l}\text { TV ads; } \\
\text { Billboards; } \\
\text { Online ads; } \\
\text { Social media; } \\
\text { Radio ads; } \\
\text { Attending com } \\
\text { munity events; } \\
\text { Mobile phone; } \\
\text { Messaging; } \\
\text { Word } \\
\text { of mouth; } \\
\text { Flyers and } \\
\text { brochures }\end{array}$ & $\begin{array}{l}\text { Radio and } \\
\text { TV shows; } \\
\text { Social media } \\
\text { awareness } \\
\text { campaign; } \\
\text { Open day }\end{array}$ & $\begin{array}{l}\text { Use of retailers } \\
\text { to } \\
\text { deliver services; } \\
\text { Use of other } \\
\text { financial } \\
\text { services' ATMs; } \\
\text { Working with } \\
\text { community } \\
\text { based organisati } \\
\text { ons }\end{array}$ & $\begin{array}{l}\text { New products; } \\
\text { Piversified products; } \\
\text { New branches; } \\
\text { No collateral } \\
\text { for loans; } \\
\text { Use of financial co- } \\
\text { operatives' card at } \\
\text { other banks' ATM; } \\
\text { Free } \\
\text { ATM withdrawal; } \\
\text { Paying bills and } \\
\text { puying online }\end{array}$ & $\begin{array}{l}\text { Community involve } \\
\text { Financial literacy to } \\
\text { diverse ethnic } \\
\text { groups } \\
\text { Community Develop } \\
\text { ment Loans; } \\
\text { Engaging in } \\
\text { voluntary programs; } \\
\text { Community support } \\
\text { groups }\end{array}$ & $\begin{array}{l}\text { Going to } \\
\text { people in } \\
\text { the street; } \\
\text { Low interest } \\
\text { rate promotion; } \\
\text { Organising pro } \\
\text { motion raffles; } \\
\text { Fast services; } \\
\text { Target group; } \\
\text { Integration }\end{array}$ \\
\hline
\end{tabular}

Figure 1: Conceptual model for measuring CFIs' entrepreneurial innovativeness

Source: Author compilation

\section{Sample Size and Sampling Technique}

The study population was the City of Tshwane in Gauteng province, South Africa. The first sample of the study was drawn from ordinary residents of the city from all walks of life. The city has a population of approximately 3.275 million residents, according to the latest 2016 survey (Statistics South Africa n.d.). In total, 303 participants were surveyed between December 2019 and March 2020, which is in line with the sample size of Cochrane's (1977) sampling formula (Bartlett, Kotrlik, and Higgins 2001, 4447).

The second sample comprised all 28 CFIs registered with the South African Treasury, including the four co-operative banks, as per the latest list obtained from the SA Reserve Bank in January 2020. All were considered for the survey, as it is a small population, and to have enough data for reliable results, all needed to be surveyed. Twenty CFIs completed the questionnaire, which represents a $71.2 \%$ response rate.

\section{Data Collection Instrument and Procedure}

Questionnaires were used to collect data for the study. For the first sample, questionnaires were administered personally by the researcher to collect primary data from the participants. For the second sample, it was assumed that, since only management of the CFIs and co-operative banks would be surveyed, emails would be 
more appropriate as the participants would be literate, and with online computer access to fill in the questionnaire. Twenty questionnaires were returned, which represents $71.2 \%$ of the registered CFIs and co-operative banks.

To establish the validity of the data collection tool, the constructs and items used in the measuring instrument had been tested in other studies (Kinyua 2016; Smakalova 2012) and had been found to be valid and reliable. A statistician also assisted in the design of the questionnaire to ensure validity. Cronbach's alpha was used to test the reliability of the constructs that have been retained after factor loadings and reliability testing.

\section{Data Analysis}

The tests that were used in the analysis included descriptive statistics, consisting of means and standard deviations; the chi-square goodness-of-fit-test; the binomial test; the one sample t-test; and factor analysis. For all questions with a five-point Likert agreement response scale, the one-sample t-test was applied to test for significant agreement/disagreement. In the same way, questions measured on a five-point semantic awareness scale were analysed to determine significant awareness or lack thereof. Questions with multiple response categories from which to choose were analysed using the chi-square goodness-of-fit test to identify which responses/options were selected with significant frequency. The binomial test was applied to test if a significant proportion of respondents selected either of the possible two response options. Factor analysis was used to determine the overall construct validity of the model variables as applied to this set of data. Cronbach's alpha was used to confirm the reliability of these composite measurements.

\section{Ethical Consideration}

The Institutional Review Board at a KwaZulu-Natal public university approved the research. The researcher also endeavoured to respect the privacy and confidentiality of all participants in the study.

\section{Results}

The analysis started with the demographic details of the respondents. The demographic information is presented in table 1 below. 
Ismaila, Gamede

Table 1: Demographic details of respondents

\begin{tabular}{|c|c|c|}
\hline Variable & Categories & $\mathbf{N}(\%)$ \\
\hline \multicolumn{3}{|c|}{ CFIs $(\mathrm{N}=20)$} \\
\hline \multirow{2}{*}{ Gender } & Male & $9(45)$ \\
\hline & Female & $11(55)$ \\
\hline \multirow[t]{4}{*}{ Qualification } & Matric or less & $3(15)$ \\
\hline & Post-matric diploma/certificate & $4(20)$ \\
\hline & Undergraduate degree & $7(35)$ \\
\hline & Postgraduate degree & $6(30)$ \\
\hline \multirow{3}{*}{ Position } & Junior management & $2(10)$ \\
\hline & Senior management & $15(75)$ \\
\hline & Other & $3(15)$ \\
\hline \multirow[t]{3}{*}{ Number of members } & $1-200$ & $2(10)$ \\
\hline & $201-1000$ & $12(60)$ \\
\hline & $1001-10000$ & $6(30)$ \\
\hline \multirow{3}{*}{ Number of non-member account holders } & None & $9(45)$ \\
\hline & $1-200$ & $10(50)$ \\
\hline & $201-1000$ & $1(5)$ \\
\hline \multicolumn{3}{|c|}{ Average annual growth rate of membership: $6 \%$} \\
\hline \multicolumn{3}{|c|}{ Consumers $(\mathrm{N}=303)$} \\
\hline \multirow[t]{2}{*}{ Gender } & Male & $168(55.4)$ \\
\hline & Female & $135(44.6)$ \\
\hline \multirow[t]{6}{*}{ Age } & $16-20$ & $24(7.9)$ \\
\hline & $21-30$ & $96(31.7)$ \\
\hline & $31-40$ & $105(34.7)$ \\
\hline & $41-50$ & $60(19.8)$ \\
\hline & $51-60$ & $14(4.6)$ \\
\hline & $60+$ & $4(1.3)$ \\
\hline \multirow[t]{4}{*}{ Highest qualification } & Matric or less & $91(30)$ \\
\hline & Post-matric diploma/certificate & $111(36.6)$ \\
\hline & Undergraduate degree & $53(17.5)$ \\
\hline & Postgraduate degree & $48(15.8)$ \\
\hline \multirow[t]{4}{*}{ Employment status } & Unemployed & $69(22.8)$ \\
\hline & Formally employed & $160(52.8)$ \\
\hline & Self-employed & $73(24.1)$ \\
\hline & Unspecified & $1(.3)$ \\
\hline \multirow[t]{3}{*}{ Job position (if formally employed) } & Management & $69(22.8)$ \\
\hline & Non-management & $95(31.4)$ \\
\hline & Unspecified & $139(45.9)$ \\
\hline
\end{tabular}

Source: Data collected by author using the questionnaires

Table 1 shows that the gender and educational demographics of the CFI respondents reflect what is expected of any individual in a position of management at a CFI. The majority of CFIs have between 210 and 1000 members; only two of them have between 1 and 200 non-members. 


\section{Consumer Knowledge about CFIs and their Products or Services}

To test this knowledge, participants were asked to rate their agreement (from $1=$ strongly disagree; to $5=$ strongly agree) to items regarding consumer knowledge about CFIs and their services. Results from a one-sample t-test revealed that the respondent CFIs believed that consumers did not know about CFIs ( $\mathrm{p}<.0005)$; nor do they know about their products $(\mathrm{p}<.0005)$. This result aligns with consumers' responses, where a significant $164(54.1 \%)$ had never heard of savings and credit co-operatives; with a further $62(20.5 \%)$ of respondents who had heard about them but did not know what they are about. Other questions were asked to assess consumers' knowledge of, and engagement with, CFIs. These included whether they were a member of any saving cooperatives; and if they had a savings plan with any saving co-operative. Results from a binomial test showed that a significant $97 \%$ of respondents were not members of CFIs, $\mathrm{p}<.0005$; and a significant $96 \%$ did not have a saving plan with any CFI, $\mathrm{p}<.0005$.

On the questions regarding reasons why many consumers were not members of CFIs, there was significant agreement that consumer respondents did not know about CFIs, with an average agreement score $(\mathrm{M})=3.93, \mathrm{p}<.0005$; and that they did not know about CFIs' products, $\mathrm{M}=4.30, \mathrm{p}<.0005$. There was also significant disagreement that that the common bond requirement is an issue for respondents, $\mathrm{M}=2.84, \mathrm{p}=.004$. This result corroborates the opinion of the CFI respondents, who believed that consumers did not know about them, $\mathrm{p}<.0005$; or their products, $\mathrm{p}<.0005$.

\section{South African CFIs' Entrepreneurial and Innovative Strategies}

To test consumer awareness of these strategies, and their implementation or lack thereof, by CFIs, consumers were asked to rate their awareness of a specific set of activities/strategies on a scale of $1=$ not at all aware; to $5=$ extremely aware. CFIs were asked to indicate if they employed a selection of specific strategies.

\section{CFIs' Marketing Strategies}

Results from a binomial test showed that only two strategies were adopted by a significant number of CFIs: handing out flyers and brochures $(\mathrm{p}=.041)$, and word of mouth (people talking about them, $\mathrm{p}=.003$ ). This result contradicts the consumer respondent answers, where about $80 \%$ and $67 \%$, respectively, said they were not aware of these activities. A significant majority of the CFI respondents also said that they did not advertise on television, radio or online.

\section{CFIs' Offensive Strategies}

The results from a binomial test showed that respondent CFIs did not adopt offensive strategies to improve their membership base. A significant majority of them did not use strategies such as offering jobs to members or account holders, $\mathrm{p}<.039$; organising raffles, $\mathrm{p}<.0005$; or giving members/account holders the option to pay bills and shop 
online, $\mathrm{p}<.0005$. This is also in line with consumer respondents who said they were not aware of these strategies, $\mathrm{p}<.0005$.

\section{CFIs’ Educational Strategies}

Results from responses relating to these strategies showed that respondent CFIs did not adopt educational strategies to improve their membership base. A significant majority of them did not use radio or television shows to promote themselves, $p=.012$. These results also confirmed the findings from the consumer respondents who also said they were not aware of the CFIs' educational activities or strategies, $\mathrm{p}<.0005$.

\section{CFIs'Partnership Strategies}

The test results showed that respondent CFIs did not adopt partnership strategies to improve their penetration rate. In particular, a significant majority of them did not allow the use of financial co-operative cards to buy or withdraw money from retailers, $\mathrm{p}<.0005$; or the use of financial co-operative cards to withdraw cash from other financial services' ATMs, $\mathrm{p}=.003$. These results agreed with those from the consumer respondents, who said they were not aware of these activities or strategies, $\mathrm{p}<.0005$.

\section{CFIs' Corporate Social Responsibility Strategies}

Results from questions relating to CSR strategies showed that respondent CFIs did not adopt these CSR strategies to improve their membership base. In particular, a significant majority of them did not adopt the strategies of organising community support groups to assist people with disabilities or during disasters, $\mathrm{p}=.003$; or giving community development loans to local community support groups, $p=.012$. This result echoes the responses from the consumers, who said they were not aware of these activities or strategies, $\mathrm{p}<.0005$.

\section{CFIs’ Differentiation Strategies}

The findings revealed that respondent CFIs did not adopt these differentiation strategies to grow their membership base. In particular, a significant majority of them did not adopt the strategies of opening new branches, $\mathrm{p}<.0005$; or providing free ATM withdrawals, $\mathrm{p}<.0005$. These results also corroborate those of the consumer respondents who said they were not aware of these activities or strategies, $\mathrm{p}<.0005$.

\section{Reliability of the Measuring Instrument and Validation of the Theoretical Constructs}

Factor analysis with Promax rotation was applied to explore the structure of the data. Items measured on a five-point Likert scale pertaining to the organisational actions were included in the initial analysis. During the process, some items were dropped because they cross-loaded onto multiple factors; or because they did not load adequately onto any factor. Three factors were extracted and rotation converged in six iterations. The factor analysis results are shown in table 2. 


\begin{tabular}{|c|c|c|c|}
\hline & \multicolumn{3}{|c|}{ Factor } \\
\hline & 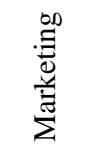 & 总 & 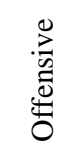 \\
\hline Cronbach's alpha & .915 & .907 & .892 \\
\hline Variance explained & 43.90 & 7.50 & 5.98 \\
\hline C10.5 Online adverts and pop-ups about financial co-operatives & .862 & & \\
\hline $\begin{array}{l}\text { C10.4 Adverts about financial co-operatives on Facebook, Twitter and other } \\
\text { social media }\end{array}$ & .847 & & \\
\hline C10.1 Adverts of saving co-operatives on TV or radio & .836 & & \\
\hline $\begin{array}{l}\text { E 13.1 Radio or TV shows promoting or discussing co-operative financial } \\
\text { institutions }\end{array}$ & .784 & & \\
\hline $\begin{array}{l}\text { C10.2 Adverts of financial co-operatives on billboards or somewhere in the } \\
\text { street }\end{array}$ & .706 & & \\
\hline E 13.2 Social media awareness campaigns about financial co-operatives & .678 & & \\
\hline C10.3 Advertising of financial co-operatives via SMS & .667 & & \\
\hline C10.7 Handing out of flyers and brochures about financial co-operatives & .584 & & \\
\hline D 11.2 Financial co-operatives actively promoting their low interest rates & .368 & & \\
\hline $\begin{array}{l}\text { G 15.4 Engagement of financial co-operatives in voluntary programmes } \\
\text { initiated by local community groups }\end{array}$ & & .898 & \\
\hline G 15.1 Community services or projects that are driven by a co-operative & & .794 & \\
\hline G 15.5 Community development loans given to local community support & & .759 & \\
\hline $\begin{array}{l}\text { G 15.3 Community support groups organised by financial co-operatives to } \\
\text { assist people with disabilities or during disasters such as flooding }\end{array}$ & & .754 & \\
\hline $\begin{array}{l}\text { D 11.3 Raffles held in shopping centres or streets where financial co-operatives } \\
\text { are promoted }\end{array}$ & & .619 & \\
\hline $\begin{array}{l}\text { G 15.2 Financial literacy sessions organised by financial co-operatives for } \\
\text { diverse ethnic groups }\end{array}$ & & .609 & \\
\hline $\begin{array}{l}\text { E } 13.3 \text { Open days organised by financial co-operatives to promote themselves } \\
\text { or their services }\end{array}$ & & .595 & \\
\hline $\begin{array}{l}\text { D 11.1 Employees of a financial co-operative approaching people in a public } \\
\text { area to explain the benefits of belonging to a CFI and asking them to join }\end{array}$ & & .569 & \\
\hline M6 Attendance of financial co-operatives at community events & & .511 & \\
\hline $\begin{array}{l}\text { F 14.3 Partnerships between financial co-operatives and community-based } \\
\text { organisations such as NGOs, or others }\end{array}$ & & .507 & \\
\hline H 16.1 The introduction of new products by financial co-operatives & & & .873 \\
\hline $\begin{array}{l}\text { F 14.2 Being able to use a financial co-operative card to withdraw from other } \\
\text { financial services' ATMs }\end{array}$ & & & .855 \\
\hline $\begin{array}{l}\text { F 14.1 Being able to use a financial co-operative card to buy or withdraw } \\
\text { money from retailers such as Shoprite, Spar, etc. }\end{array}$ & & & .759 \\
\hline H 16.5 Free ATM withdrawal & & & .756 \\
\hline H 16.3 Diversity in the products they offer & & & .680 \\
\hline D 11.4 Ability to pay bills and shop online with CFI cards & & & .543 \\
\hline $\begin{array}{l}\text { Kaiser-Meyer-Olkin Measure of Sampling Adequacy }(\mathrm{KMO})=.902 \text {; } \\
\text { Bartlett's test of sphericity }(\mathrm{df}=\mathbf{3 0 0})=5586.274, \mathrm{p}<.0005\end{array}$ & & & \\
\hline
\end{tabular}

Source: The study results 
A Kaiser-Meyer-Olkin measurement of sampling adequacy (KMO) value of .902 indicates that a successful and reliable extraction process has taken place. In addition, a significant Bartlett's test result indicates that correlations between items are not too low for successful extraction to occur. Three factors were extracted and account for $62.20 \%$ of the variation in the data. These factors were C10.1-10.7 (marketing); D11.1-11.4 (offensive strategies); and G15.1-15.5 (social responsibility). Cronbach's alpha was used to test the reliability of each factor. The factor loadings, as well as the Cronbach's alpha values are shown in table 2, where all three factors have an alpha value that is greater than .7, confirming the reliability of each factor as a composite measure.

\section{Awareness of the Strategies as a Whole}

Further analysis was done on the three composite measures that loaded together to test, on the one hand, for significant awareness by consumers (or lack thereof) of the CFIs' strategies, as represented by the three composite measures; and on the other hand, to determine the extent to which these strategies are applied by respondent CFIs (how many CFIs apply which strategies and how many?). Results from a binomial test (figure 2) revealed that not many strategies have been adopted or used by respondent CFIs, echoing consumer "lack of awareness" about them. For instance, regarding marketing strategies, $10 \%$ of all respondent CFIs did not implement any. Just $10 \%$ applied seven of them, which is the highest number of these strategies adopted. Of the respondent CFIs, $10 \%$ did not apply any CSR strategies at all. Only 9\% used all nine strategies. As for offensive strategies, $40 \%$ of respondent CFIs did not apply any. Just $15 \%$ applied four of them, the maximum number of those strategies that are adopted. This may not be enough for these CFIs to grow their membership base, considering the positive effect these strategies have had on CFIs' success in other countries, as discussed earlier.

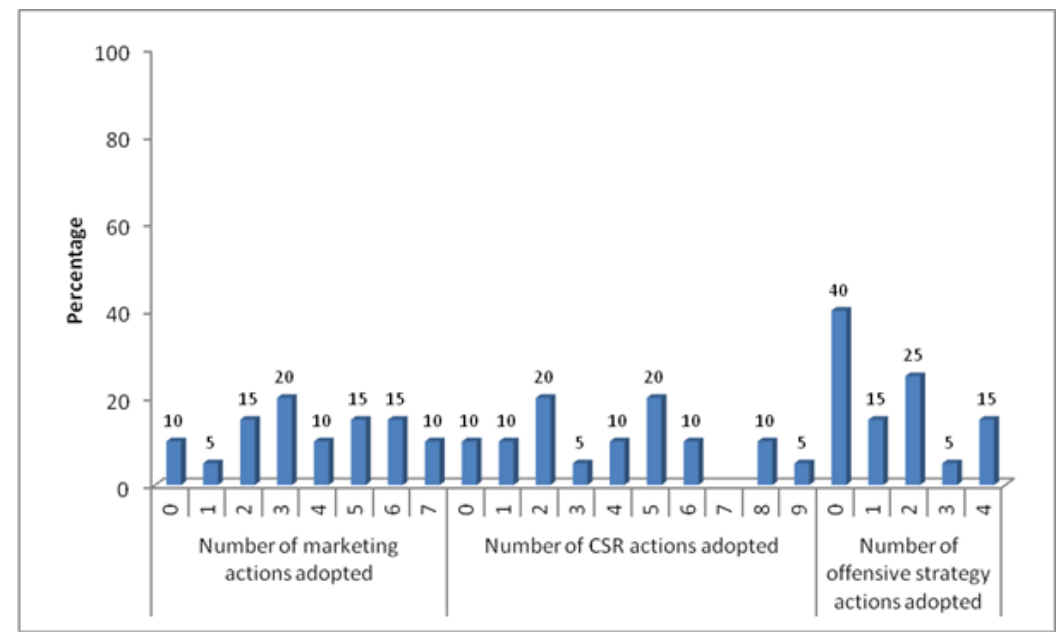

Figure 2: Number of strategies adopted per composite measure

Source: The study results 
More analysis was conducted to determine whether significant proportions of respondent CFIs adopt a certain number of these activities or strategies. Results from a binomial test revealed that a significant $85 \%$ of the CFI's indicated that they applied at least one of the nine activities under "marketing strategy" $p=.003$. A significant $80 \%$ of the CFIs indicated that they implemented at least one of the 10 CSR activities, $\mathrm{p}=.012$. The implementation of one activity would not be sufficient to make any difference, and results from a binomial test showed that a significant proportion (80\%) of respondents said they adopted two, or fewer, of the activities included in the offensive strategies, $\mathrm{p}=.012$. There is no evidence that a significant proportion of respondent CFIs adopt more than two of the activities included in the offensive strategies. Further analysis indicated that a significant proportion adopts, at most, five activities under marketing and CSR $(\mathrm{p}=.041)$.

For the three composite measures, it can be seen from the analysis that, overall, a significant number of respondents had not adopted enough of the activities listed under any of the three measures to make an impact on their growth, in general; and on increasing their membership numbers in particular. However, this result is only applicable to this sample of 20 respondents CFIs, and not to the entire population of 28 registered CFIs.

\section{Proposed Assessment Model}

The conceptual framework model (figure 1) for the study was based on international best practice drawn from numerous studies. After its application in this study, it has been revised; and a model for South African CFIs, based on the factor analysis, KaiserMeyer-Olkin measurement of sampling adequacy (KMO), and a reliability test have been proposed. This is presented in figure 3 . 


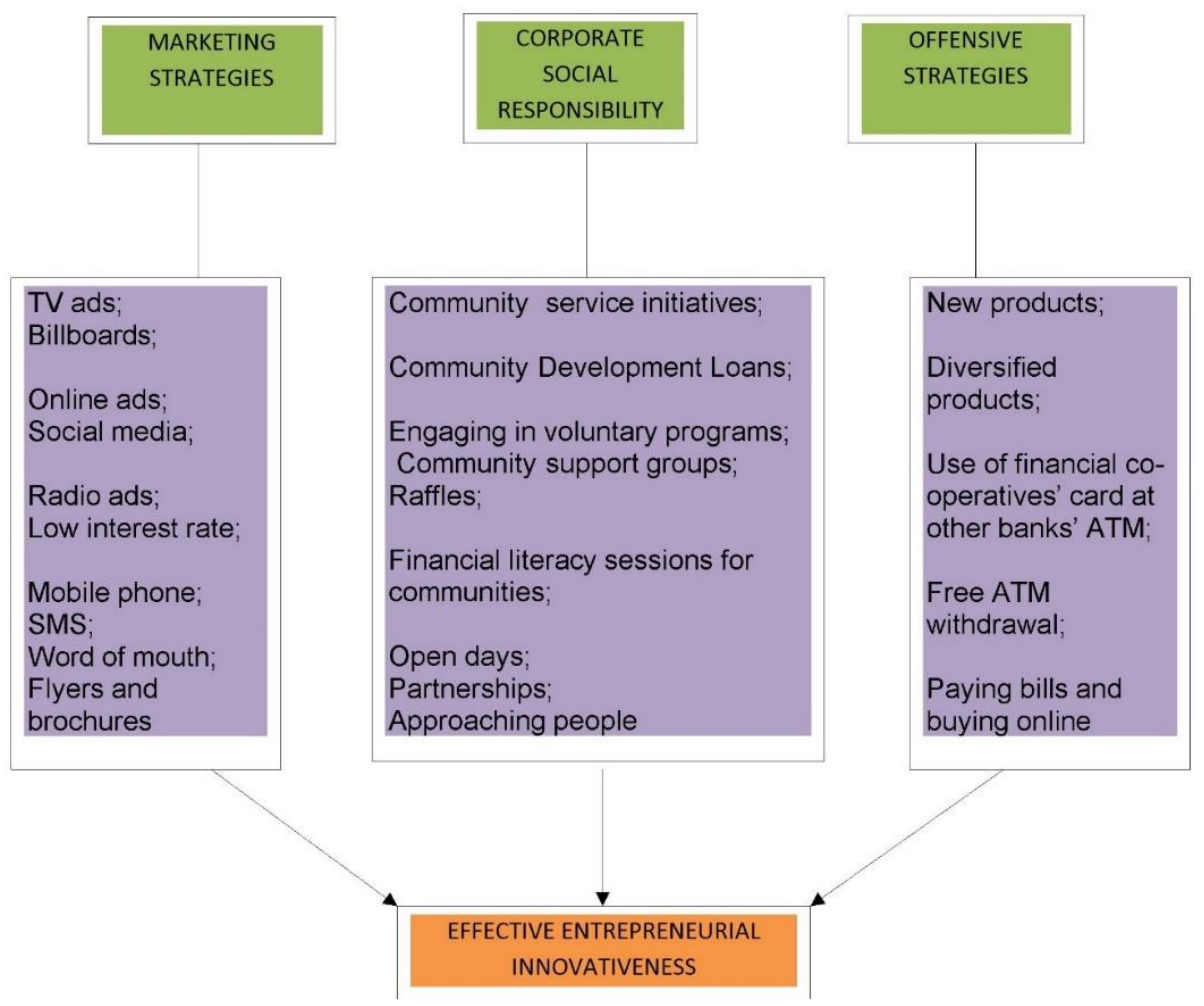

Figure 3: Proposed assessment model

Source: by the author, based on the study results

\section{Discussion of the Findings}

This section discusses the results that have been presented in the previous sections. The penetration rate of CFIs in the South African economy is very low compared to other countries, as has been discussed earlier, and the South African CFI sector is lagging behind that of those countries. The findings regarding consumer knowledge about CFIs and their products or services are in line with the financial co-operative sector in South Africa being exceedingly small, with a low penetration rate (.01\%). This is not surprising, since the literature had already indicated the very low penetration rate of the CFI sector in South Africa (Mushonga et al. 2018; WOCCU 2018). The point is that people need to know about something to show interest in it. The City of Tshwane population, based on the 2016 survey, was estimated at around 3275000 . There are four financial co-operatives based around the city with a total membership of about 2 056, based on the 2018 and 2019 updated lists. This means that, of the city's population, a mere $0.063 \%$ claim CFI membership. This reflects the national membership. On the other hand, if most people do not know about CFIs, one would not expect many to have any saving plans with them. The issue of social capital 


\section{Ismaila, Gamede}

(membership) cannot be overlooked within the CFI sector as it is probably the most important factor. This is supported by the findings of Mushonga et al. $(2018,262)$, that the major drivers of CFI performance seem to be leveraging on social capital to eliminate poverty. Anstead $(2008,8)$ argues that gaining new members "requires a twostep sale. First, people need to become aware of what credit unions are and their eligibility to join. Only then, can they be attracted by a specific credit union." The disagreement with "common bond" being an issue for participants makes sense, as most people would want to engage financially with those that they know and trust.

The findings regarding awareness of marketing strategies show that most respondents do not know about CFIs. That might be because they are not visible in places where they can be seen or heard. Do CFIs need to market themselves? If companies like Coca Cola or Discovery still market themselves, one would assume that it is because marketing works. The findings also show a lack of awareness of offensive strategies by CFIs. Nonetheless, these strategies seem to be very effective in a country with a successful financial co-operative sector, like Kenya. Kinyua et al. $(2015,142)$ found that there was a significant positive correlation between offensive strategies and Kenyan SACCOSs' financial performance and success. So, why would SA financial cooperatives not adopt them? The results further show that consumers are unaware of educational activities by CFIs. Stokvels, which are a form of informal financial cooperative in South Africa, are well known on TV shows; and they are immensely popular, even though one cannot say for certain that the TV shows are the only reason for their popularity. Most businesses use social media nowadays, because they have become platforms for almost everything. Additionally, many businesses organise open days to promote themselves, especially if they are a new business or have opened new branches in other areas.

The findings also show a low level of awareness of CFI partnership strategies. However, these strategies have been useful to financial co-operatives in countries with successful CFI sectors. For instance, one of the key success factors of a Canadian credit union is "delivery channels," which focuses on enhancing the existing channels and developing new channels, such as wireless access and grocery store branches, so their clients can complete transactions easily and in any way they wish to (Schoemaker et al. 2002, 24). The South African CFIs also lack adequate CSR strategies, and it has been found that CSR strategies benefit both financial co-operatives and the communities they serve. Kinyua $(2016,93)$ found that CSR activities, such as integrating social concerns into business, good ethical values, striving to satisfy the community, and engaging in environmental stewardship, contribute to a better society, thus improving Kenyan SACCOs' images and contributing to their success.

The results further showed significant disagreement that respondents were aware of any CFI differentiation activity. Although these activities may be costly for CFIs, especially for the very small and/or new ones, they may help to turn things around for them. In Canadian credit unions for example, new branches are a distribution channel for 
products and services; brand promotion and recognition; and differentiation (Schoemaker et al. 2002, 24). Koskei and Naibei (2017) found that that SACCO members' loyalty is influenced by interest rates, mode of disbursement and variety of financial products.

\section{Practical Implications}

The proposed assessment model in this study may be a starting point for CFIs, as it will allow them to establish where they are currently, and then use the model to constantly measure their entrepreneurial innovativeness and keep up with the adoption of key success factors to improve the sector's penetration rate and performance.

\section{Limitations and Recommendation for Future Research}

The study, despite using a quantitative survey, did not manage to survey all registered CFIs in South Africa, and focused on only one city. Twenty CFIs out of 28 participated. It is recommended that, in future research on this topic, and because there are only a few CFIs, studies should endeavour to survey all registered CFIs to generalise the results.

From the general consumer perspective, the main limitation of the study is that only residents of one metropolitan area were considered for the survey. It is recommended that a country-wide study, with a representative sample, be considered for future studies to generalise the findings to the entire country. However, the study serves as a basis for wider studies, or its replication in other regions of the country, or even internationally.

\section{Conclusion}

Financial co-operatives play an important role in poverty reduction and financial inclusion across the globe. Despite this, no study has been conducted in South Africa to try and find the reasons behind the sector's very low penetration rate. Considering that, this study sought to determine the reasons for the low penetration rate of South African CFIs by investigating both the supplier and consumer perspectives regarding the low penetration rate, as well as the CFIs' use of key success factors or strategies that indicate their entrepreneurial innovativeness. In addition, a valid and reliable measuring instrument is recommended to promote effective entrepreneurial innovativeness. The most important finding of the study is the lack of awareness of CFI activities and strategies by a significant majority of the respondents - a result echoed by the respondent CFIs themselves. The study also found that respondent CFIs lack entrepreneurial innovativeness, which could help improve their public image and draw more members into the sector.

In order to determine the possible reasons behind the low penetration rate of South African CFIs, a conceptual model was designed, from which the questionnaire items were developed to collect data from both consumers and suppliers. The model was 
subsequently revised, resulting in the final model, proposed for measuring CFIs' entrepreneurial innovativeness. The various tests employed in the study suggest that the instrument developed in this study has been able to give statistically significant explanations for the low penetration of SA financial co-operatives; and may be taken as a reliable instrument. The instrument was developed by the researcher from a conceptual model that came out of studies by other authors (Kinyua 2016; Smakalova 2012), where it was found to be both valid and reliable.

The study results suggest that the South African CFI sector needs to adopt and implement a systematic programme that will enable it to reach a far larger number of consumers. The findings may also give the government, and NGOs who are stakeholders, a better idea of what they should do to assist the sector in dealing with this problem. It is hoped that the assessment model will assist CFIs, on their side, to design and implement an effective entrepreneurial and innovative programme to improve their membership penetration and sector performance. The study findings also contribute to the current body of knowledge by adding new theory on the specific topic of the reasons for the low penetration rate of South African CFIs, which has not been explored by past studies.

\section{References}

Anstead, M. 2008. "Awareness Is the First Step to Attracting New Members." Credit Union Journal 12 (15): 8-8. Accessed 14 June, 2020.

http://web.b.ebscohost.com.ukzn.idm.oclc.org/ehost/pdfviewer/pdfviewer?vid=1\&sid=bf8 7ee05-7331-4b08-8b95-2cea3284ddfb\%40pdc-v-sessmgr05.

Bank Association South Africa. 2017. "Towards a Financial Inclusion Strategy.” Accessed November 17, 2017. http://www.banking.org.za/what-we-do/overview/towards-afinancial-inclusion-strategy.

Bartlett, J. E., J. W. Kotrlik, and C. C. Higgins. 2001. “Organizational Research: Determining Appropriate Sample Size in Survey Research.” Information Technology, Learning, and Performance Journal 19 (1): 43-50. Accessed August 10, 2019. https://www.opalco.com/wp-content/uploads/2014/10/Reading-Sample-Size1.pdf.

Birchall, J. 2013. "Resilience in a Downturn: The Power of Financial Co-operatives.” Accessed August 20, 2017.

http://www.ilo.org/wcmsp5/groups/public/ed_emp/emp_ent/coop/documents/publication/ wcms207768.pdf.

Boysen, V., and R. Sahlberg. 2008. "The Key Success Factors of Grameen Bank: A Case Study of Strategic, Cultural and Structural Aspects." MBA Thesis, Lund University.

Christensen, K. S. 2004. "A Classification of the Corporate Entrepreneurship Umbrella: Labels and Perspectives." International Journal of Management Enterprise Development 1 (4): 301-315. https://doi.org/10.1504/IJMED.2004.004635. 
Cochrane, W. G. 1977. Sampling Techniques, 3rd edition. New York: John Wiley and Sons.

Companies and Intellectual Property Commission. 2017. "Registering your Co-operative." Accessed January 24, 2018. http://www.cipc.co.za/index.php/register-your-business/cooperatives/.

Corcoran, H., and D. Wilson. 2010. "The Worker Co-operative Movements in Italy, Mondragon and France: Context, Success Factors and Lessons." Canadian Worker Cooperative Federation. Accessed November 20, 2017. http://communitywealth.org/sites/clone.community-wealth.org/files/downloads/paper-corcoran-wilson.pdf.

Department of Trade and Industry. 2012. "Promoting an Integrated Co-operative Sector in South Africa 2012-2022." Accessed October 10, 2017. http://www.dti.gov.za/economic_empowerment/docs/coops/legis_policy/coopstrategy.pdf.

Entrepreneur. 2009. "What should I Know about a Co-operative before Registering one and how do I Go about it?" Accessed March 15, 2018. http://www.entrepreneurmag.co.za/askentrepreneur/doing-business-in-sa-ask-entrepreneur/what-should-i-know-about-a-cooperative-before-registering-one-and-how-do-i-go-about-it/.

Finmark Trust. 2014. "Understanding Financial Co-operatives: South Africa, Malawi and Swaziland.” Accessed September 11, 2017. http://www.finmark.org.za/wpcontent/uploads/pubs/Rep_Financial-Co-operatives20142.pdf.

Freeman, R. E., and J. McVea. 2001. “A Stakeholder Approach to Strategic Management.” Working Paper No. 01-02, University of Virginia. https://doi.org/10.2139/ssrn.263511.

Gogo, P. A., and O. Oluoch. 2017. "Effect of Savings and Credit Co-operative Societies' Financial Services on Demand for Credit by Members: A Survey of Deposit-taking SACCOS in Nairobi." International Journal of Social Sciences and Information Technology 3 (8): 2410-2421.

Hill, M. E. 2003. “The Development of an Instrument to Measure Intrapreneurship: Entrepreneurship within the Corporate Setting." MA dissertation, Rhodes University. Grahamstown.

Holtzman, Y. 2014. "A Strategy of Innovation through the Development of a Portfolio of Innovation Capabilities.” Journal of Management Development 33 (1): 24-31. https://doi.org/10.1108/JMD-11-2013-0138.

International Co-operative Alliance. 2015. "What is a Co-operative?" Accessed June 17, 2017. https://www.ica.coop/en/cooperatives/what-is-a-cooperative.

Ireland, R. D., D. F. Kuratko, and M. H. Morris. 2006. “A Health Audit for Corporate Entrepreneurship: Innovation at all Levels: Part I.” Journal of Business Strategy 27 (1): 10-17. https://doi.org/10.1108/02756660610640137. 
Jaseviciene, F., V. Kèdaitis, and S. Vidzbelytè. 2014. “Credit Unions' Activity and Factors Determining the Choice of them in Lithuania.” Ekonomika no. 93: 117-130. Accessed June 19, 2020. https://etalpykla.lituanistikadb.lt/object/LT-LDB0001:J.04 2014 1447862679313/J.04 2014 1447862679313.pdf.

Karakaya, F., and P. Yannopoulos. 2011. "Impact of Market Entrant Characteristics on Incumbent Reactions to Market Entry. Journal of Strategic Marketing 19 (2): 171-185. https://doi.org/10.1080/0965254X.2011.557741.

Kassa, A. G., and S. Raju. 2014. "Corporate Entrepreneurship and Innovation.” European Journal of Business and Management 6 (31): 50-68.

Kinyua, Jesse Maina. 2016. "Stakeholder Management Strategies and Financial Performance of Deposit-taking SACCOs in Kenya." PhD thesis. Nairobi: Jomo Kenyatta University of Agriculture and Technology.

Kinyua, J. M., M. I. Amuhaya, and G. S. Namusonge. 2015. "Stakeholder Management Strategies and Financial Performance of Deposit-taking SACCOs in Kenya." International Journal of Business and Social Science 6 (9): 139-158.

Koskei, R. K., and K. Naibei. 2017. "Determinants of Member Loyalty among SACCOs. A Survey of selected SACCO's in Kericho County, Kenya." International Journal of Economics, Commerce and Management no. 21: 34-54.

Mathuva, D. 2016. "Revenue Diversification and Financial Performance of Savings and Credit Co-operatives in Kenya." Journal of Co-operative Organization and Management 4 (1): 1-12. https://doi.org/10.1016/j.jcom.2015.11.001.

McWilliams, A., D. S. Siegel, and P. M. Wright. 2006. “Corporate Social Responsibility: Strategic Implications.” Journal of Management Studies 43 (1): 1-19. https://doi.org/10.1111/j.1467-6486.2006.00580.x.

Molokwu, V. B., J. Barreria, and B. Urban. 2013. "Entrepreneurial Orientation and Corporate Governance Structures at the Firm Level in the South African Oil and Gas Industry." SA Journal of Human Resource Management 11 (1): 1-15. https://doi.org/10.4102/sajhrm.v11i1.443.

Mushonga, M., T. G. Arun, and N. W. Marwa. 2018. "Drivers, Inhibitors and the Future of Cooperative Financial Institutions: A Delphi Study on South African Perspective." Technological Forecasting and Social Change 133: 254-268. https://doi.org/10.1016/j.techfore.2018.04.028.

Odhiambo, S. P. O. 2019. "Determinants of Financial Performance of Savings and Credit Cooperative Societies in Nakuru Town, Kenya." Reviewed Journal International of Business Management 1 (1): 42-53. https://doi.org/10.32898/ibmj.01/1.4article17. 


\section{Ismaila, Gamede}

Oluwatayo, I. B. 2012. "Mobile Phones as Mobile Banks and Credit Outlets: The Experiences of Farming Households in Rural Southwest Nigeria." International Journal of Computing and ICT Research 6 (1): 52-59.

Paredes, C. Oswaldo. 2008. "Ecuador: Savings Mobilization in 14 Credit Unions." Accessed 30 July 2018. woccu.org. https://www.woccu.org/documents/Ch_8.

Peels, Rafael. 2013. "Resilience in a Downturn: The power of Financial Co-operatives." Accessed May 9, 2017. globalcube.net.

https://www.globalcube.net/clients/eacb/content/medias/events/2nd_Day_with_Academics _and_Stakeholders/Presentations/Rafael_Peels_ILO_13.05.2013_III.pdf.

Philip, K. 2003. "Co-operatives in South Africa: Their Role in Job Creation and Poverty Reduction." Accessed 16 December 2016. https://waqfacademy.org/wpcontent/uploads/2013/03/Kate-Philip-KP.-10_2003.-Co-operatives-in-South-Africa-TheirRole-in-Job-Creation-and-Poverty-Reduction.-South-Africa.-Kate-Philip.pdf.

Sauli, Nomadelo. n.d. "CFI Start-up Guide. South African Treasury.” Accessed September 12, 2018. http://www.treasury.gov.za/coopbank/CFI\%20start\%20up\%20guide.pdf/.

Schoemaker, P. J. H., G. Hofheimer, D. Randall, R. Parayre, and F. Schuurmans. 2002. “Key Success Factors: How to Thrive in the Future.” Accessed March 5, 2019. cues.org. https://www.cues.org/repository/key_success_factors.pdf.

Smakalova, P. 2012. “Generic Stakeholder Strategy.” Economics and Management 17 (2): 659-663. https://doi.org/10.5755/j01.em.17.2.2195.

Statistics South Africa. n.d. "City of Tshwane Population.” Accessed November 15, 2019. http://www.statssa.gov.za/?page_id=1021\&id=city-of-tshwane-municipality/.

Strandberg, Coro. 2010. "Credit Union Social Responsibility: A Sustainability Road Map Policy Brief.” Accessed 25 April 2018. https://filene.org/assets/pdfreports/207_Strandberg_Sustainability_Road_Map.pdf.

The World Bank. 2014. "Financial Inclusion: International Bank for Reconstruction and Development." Accessed 20 December 2017. http://siteresources.worldbank.org/EXTGLOBALFINREPORT/Resources/88160961361888425203/9062080-1364927957721/GFDR-2014_Complete_Report.pdf.

Van der Walt, Louw. 2008. "Collective Entrepreneurship as a Means for Sustainable Community Development: A Co-operative Case Study in South Africa." Accessed October 2, 2017. redalyc.org. http://www.redalyc.org/pdf/631/63111251001.pdf.

Van Vuuren, J. J., D. Groenewald, and M. S. V. Gantsho. 2009. "Fostering Innovation and Corporate Entrepreneurship in Development Finance Institutions." Journal of Contemporary Management no.6: 325-360. 


\section{Ismaila, Gamede}

World Council of Credit Unions. 2015. "International Lessons for Young Adult Membership Growth. Technical Guide.” Accessed February 18, 2020.

https://www.woccu.org/documents/young-adult-tech-guide-hi-res.

World Council of Credit Unions. 2018. "Statistical Report." Accessed October 8, 2019. https://www.woccu.org/documents/2018_Statistical_Report. 